\title{
Diagnostic for COVID-19: Application for Developing
} Countries

\author{
ARYATI ARYATI', ERSA BAYUNG MAULIDAN', MUHAMMAD MIFTAHUSSURUR ${ }^{2,3 *}$ \\ 'Department of Clinical Pathology, Faculty of Medicine, Universitas Airlangga - Dr. Soetomo Teaching \\ Hospital, Surabaya, Indonesia. \\ ${ }^{2}$ Gastroenterology and Hepatology Division, Department of Internal Medicine, Faculty of Medicine-Dr. \\ Soetomo Teaching Hospital, Universitas Airlangga, Surabaya 60131, Indonesia \\ ${ }^{3}$ Institute Tropical Disease, Universitas Airlangga, Surabaya, East Java, 601 15, Indonesia \\ *Corresponding author: \\ Email ID: muhammad-m@fk.unair.ac.id
}

Received: 08.04.20, Revised: 22.05.20, Accepted: 13.06.20

\begin{abstract}
We summarized the various serological and molecular examination modalities for COVID-19. RT-PCR instrument selection is important. Closed system has the advantage of automatic RNA extraction, thereby reducing the risk of contamination and false negatives results, but the cost is high. In contrast, open system has lower cost, but the RNA extraction must be performed manually. Thus, it requires additional facilities and expert laboratory staff. In addition, it has a higher false negative rate and the risk of contamination towards laboratory staff. Among several number of gene targets, it is recommended to use specific gene targets according to $\mathrm{WHO}$ and CDC. Although the current gold standard diagnosis of COVID-I9 is the RNA examination using RT-PCR, but the availability of this instrument is not evenly distributed. Therefore, alternative examination is needed. Serology is a quick and easy examination, thus it can be used for screening and helping diagnose COVID-19. However, several aspects are needed. The detected target is antigen or antibody. The detected antigen is a specific protein from the virus, but the antigen is only detected when the virus is actively replicating and more effective at acute phase. Antibodies are more effective because they can last for a long time. Total antibodies have the highest sensitivity and can increase the sensitivity of RNA tests when combined. The time of collection and specimen type used are also important because some specimens have low sensitivity.
\end{abstract}

Keywords: COVID-19, RT-PCR, Serology, Diagnostic test

\section{INTRODUCTION}

Corona virus disease (COVID-19) is an infectious disease caused by the latest coronavirus strain severe acute respiratory syndrome coronavirus 2 (SARS-CoV-2), first appeared at the end of 2019 in Wuhan, China. ${ }^{[1]}$ This disease spreads very quickly throughout the world, thus WHO declared COVID-19 as a pandemic on March 11, 2020. The diagnosis is based on clinical symptoms, such as fever, dry cough, shortness supported by confirmation of SARS-CoV-2 infection. ${ }^{[2]}$ There is a number of modalities used for confirmation, both serological tests for $\lg G$ and $\lg M$ antibodies, or molecular examinations with real-time reverse transcriptase polymerase chain reaction ( $r R T-P C R$ ) as the gold standard. ${ }^{[3]}$

The pathogenesis of COVID-19 is still unclear. Some experts assume the disease mechanism is similar to MERS-CoV. Viruses enter cells through direct fusion of viruses and plasma membranes. The protein spike (S) present in the coronavirus binds to the ACE2 receptor. These receptors exist in various organs, but are most numerous in the pulmonary alveolar. Thus, the symptoms which appear mostly attack in the lower respiratory tract. After entering the cell, the virus is replicated by the Nucleocapsid (N) protein and RNAdependent RNA polymerase ( $R d R p)$ activity, then the newly formed virus will be released out of the cell. ${ }^{[4]}$ The virus will be recognized as an antigen and stimulate the immune system by mediating $B$ cells and T cells. Antibodies against SARS-CoV, specifically specific to $S$ protein and $N$ protein, are formed as $\lg M$ and $\lg G$. $\lg M$ will disappear after 12 weeks, while $\lg G$ will last for a long time. ${ }^{[5]}$.

COVID-19 spreads very quickly, suggesting that the number of samples is inversely proportional to the number of referral laboratories. This is certainly influential on the length of diagnosis time. The availability of instruments for diagnosis in each region must be ensured so that diagnoses can be made quickly and accurately. Clinical and analytical validation are essential for all commercial instruments, including RT-PCR before being widely used. The risk of false positives and negatives will aggravate efforts to prevent the spread of this disease. The availability of 
validated diagnostic instruments and the uniformity of inspection protocols in each country are important aspects. ${ }^{[6]}$ This review is important to observe the various serological and molecular examination modalities for COVID-19.

\section{Diagnosis}

Specific diagnoses are molecular examinations of airway samples collected from throat swabs, sputum, endotracheal aspirate, and bronchoalveolar lavage. Viruses can also be detected in the stool and blood in severe cases. ${ }^{[7]}$ Definitive diagnosis for COVID-19 is by rRT-PCR examination using samples from the lower airway. Another modality is serological examination which detects the presence of antigens and antibodies in the form of $\lg M, \lg G$, or total antibodies. This examination can be performed quickly and easily, but the validation is important. ${ }^{[8]}$

Other laboratory results are usually not specific. Complete blood examination usually shows a normal or low number of leukocytes. The presence of lymphopenia (lymphocytes $<1500 / \mathrm{mm}^{3}$ ) is associated with the severity of the disease. Platelets are usually normal or slightly low. ${ }^{[9]}$ Some cases report an increase in c-reactive protein and erythrocyte sedimentation rate but normal procalcitonin. Increased procalcitonin indicates bacterial co-infection. Increased aspartate transaminase, alanine transaminase, serum creatinine, prothrombin time, D-dimer, and lactate dehydrogenase are related to the severity of the disease..$^{[10,11]}$

Chest X-ray examination usually shows bilateral infiltrates, but in some cases shows normal picture. Chest CT scan is more sensitive and specific. The CT scan shows infiltrates, ground glass opacities, and sub-segmental consolidation. Abnormalities of CT scans also appear in asymptomatic patients, suggesting to be used to diagnose COVID-19 in suspected patients with negative molecular test results. ${ }^{[12]}$

\section{Molecular Examination}

Molecular examination is a major modality in the diagnosis of COVID-19. The method currently most used widely is RT-PCR. There are currently 3 target genes used to detect the SARS-CoV-2 virus. The target genes used are RdRP in the open reading frame (ORFlab) region, envelope protein (E) gene, and nucleocapsid (N) gene. Both the RdRP and $E$ genes have higher sensitivity than the $\mathrm{N}$ gene, but the $\mathrm{N}$ gene is more specific. ${ }^{[13]}$

The rRT-PCR is the most often used method to detect coronavirus. This method converts SARSCoV-2 RNA into DNA by reverse transcriptase. In DNA form, amplification is continued with 3 stages (denaturation, annealing, and extension) and will be repeated until 30-40 cycles. This method is chosen because it is specific, easy, and quantitative. However, it is vulnerable to contamination and requires a long time. The experts then developed this method using TaqMan in diagnosing HCoV. Recently, more developed methods use 2 TaqMan probes to increase sensitivity. The development is very helpful in detecting SARS-CoV-2 because the LoD reaches 1 RNA copies/reaction. However, the real challenge is the rapid mutation of the virus. ${ }^{[14]}$

The accuracy of molecular examinations depends on the quality of the examined specimens. Specimens examined can be from the upper or lower airways (nasal swab, throat swab, sputum, and bronchoalveolar lavage). The Center of Disease Control (CDC) recommends collecting specimens from nasopharyngeal swabs only because it has greater positivity rate than oropharyngeal swabs. If the oropharyngeal swab is taken, it is recommended to put it in the same tube as the nasopharyngeal swab specimen. Alternative specimens if nasal swabs are not possible are oropharyngeal swabs, mid-turbinate nasal swabs, and nasal aspirates. Sputum is also recommended if the patient produces adequate sputum. The highest levels of positivity of the lower airway samples are found in bronchoalveolar lavage and sputum with percentages of $93 \%$ and $72 \%$, respectively, but it is invasive and has droplet risks. The highest positivity sample from the lower airway is nasopharyngeal swab (63\%), while for oropharyngeal swab is only $46 \%$. The lowest positivity rate is urine, almost $0 \%{ }^{[15]}$ Transport media for nasopharyngeal swab specimen is scarce, thus CDC allows acceptable alternative specimens and transport media if standard media is not available. Alternative media are phosphatebuffered saline, amies, and saline, but the examination must be performed within 24 hours. ${ }^{[16]}$

Time of collection is an important factor influencing the diagnosis of COVID-19 because the amount of virus is very influential. The SARSCoV-2 positive rate in upper airway specimens reaches a peak on the 7-10 days after onset, then decreases constantly. Specimens from the lower airway have the highest positive rate if taken at 3 weeks or more after onset. A study in China showed that the site of RNA shedding in patients with SARS-CoV-2 was more similar to influenza patients than with SARS-CoV or MERS-CoV. The median time of virus shedding in each specimen was 12 days on nasopharyngeal swab, 19 days in sputum, and 18 days in feces. ${ }^{[17]}$ The virus was 
still detected in $20.9 \%$ patients studied even after more than 30 days after onset. ${ }^{[15]}$

The selection of PCR devices should also be considered. There are 2 types of PCR systems, open and closed systems. Most of the PCR devices are closed system; they require reagents, consumables, or other specific hardware made by a manufacturer, thus certainly requiring a lot of costs and reducing the flexibility of tool users. The advantage of a device with a closed system is that RNA extraction can be performed automatically, suggesting that the risk of staff contamination is smaller. Devices with closed system only require biosafety cabinet 2 a which is available in many laboratories. On the other hand, open system allows users to choose the requirement reagents, consumables, and instruments. This allows the user to optimize the tool according to the needs and conditions of the PCR, but RNA extraction must be performed manually. This manual extraction causes a false negative rate, and the risk of contamination to the staff increases. Therefore, it needs the adequate facilities and expert laboratory staff. Laboratories with a minimum open system must have a biosafety level 2 with negative pressure. Other important factors to consider are the capacity, speed, and compatibility of the device. ${ }^{[18]}$

The RT-PCR examination conducted by the CDC uses primer from the $N(N 1$ and $N 2)$ gene and the RNase $P$ gene to ensure that the RNA extraction process is going well, while WHO uses RdRP gene and the E gene. John Hopkins Center for Health Security tries to compare the sensitivity and specificity of various primers used in several countries. Sensitivity can be seen from how small the Limit of Detection (LoD). Most kits are considered good performance if LoD is below 10 RNA copies per reaction. Lower LoD is considered more sensitive. Specificity is measured from the ability of the kit to distinguish SARS-CoV-2 RNA from other similar pathogens. The specificity of a primer will increase if it has the least resemblance to another viral RNA. The primers with the highest specificity are those which use the $N$ gene. In addition, the kit used must have no cross reaction with other viruses. ${ }^{[19]}$

Indonesia uses devices targeting the Orflab $(R d R p)$ and $E$ genes, but the number of PCR machines used is still insufficient for Indonesia's vast population. On May 20, 2020, Malaysia, which was considered successful in preventing the spread of COVID-19, performed 569 tests per thousand population with 104 confirmed cases per day per 1 million population. South Korea conducts 224 tests per thousand population with 0.41 confirmed cases per 1 million population. Otherwise, Indonesia only conducts 16 tests per thousand population with 1.96 confirmed cases per 1 million population. ${ }^{[20]}$

\section{Molecular Rapid Test}

Molecular rapid test is a simple, quick examination (less than 1 hour), and has been approved by the American Food Drug Administration (FDA). ${ }^{[21]}$ This test includes cartridge-based examinations with a choice of instruments, such as Abbott ID Now (Abbott Laboratories), Biofire Film Array (bioMerieux), Cobas Liat (Roche Diagnostics), and GeneXpert (Cepheid). This instrument has a very important role in expanding the range of diagnoses of SARS-CoV-2. The Xpert Xpress SARS-CoV-2 (Cepheid) has received EUA from the FDA and can be done using the GeneXpert tool, a tool that has been widely used for HIV and TB testing, especially in countries with low and middle income. ${ }^{[8]}$

Another instrument that uses cartridges is Vivalytic COVID-19 (Bosch, Germany), which can detect SARS-CoV-2 in less than 2.5 hours. This instrument can detect SARS-CoV-2 and 9 other respiratory viruses, including influenza $A$ and $B$. The samples used are nasopharyngeal swabs or oropharyngeal swabs. Cartridges that already contain samples are examined using a Vivalytic analyzer. ${ }^{[22]}$ Abbott ID NowTM COVID-19 is an instrument that can detect SARS-CoV-2 in just 5 minutes. The method used is isothermal nucleic acid amplification to detect SARS-CoV-2 virus RNA quantitatively. The only equipment needed is ID Now, which is only the size of a toaster and quite light. The target gene used is $R d R p$, and the sample used can be from nasopharyngeal and oropharyngeal swabs. One kit contains 24 tests, positive controls, negative controls, swabs for sampling, and pipettes. This instrument has also received EUA from the FDA and has spread widely throughout the world. ${ }^{[22]}$

The most recent method of isothermal nucleic acid amplification test is loop-mediated isothermal amplification (LAMP) which has high efficiency. This method is commonly used for DNA and RNA amplification with a high degree of sensitivity and specificity. This advantage is obtained because this method uses six target sequences which are recognized by 4 different primers simultaneously. This method is fast and does not require expensive reagents and instruments, so it can reduce the costs needed to detect coronavirus. Analysis of LAMP amplification results generally uses gel electrophoresis. In addition, it can use precipitation from magnesium pyrophosphate or fluorescent staining. Analysis methods other than gel electrophoresis can be 
monitored in real time, so it is more effective than end point detection. ${ }^{[23]}$

The development of this LAMP method is sequence-specific LAMP-based methods. This method can separate the specific and nonspecific signals which cannot be done with classic LAMP method. The drawback of this method is the temperature needed for to run optimally is to be at $65^{\circ} \mathrm{C} .{ }^{[24]}$ Comparison of molecular rapid test instruments is presented in Table 1. Sensitivity and specificity are taken from each insert kit.

Table 1: Comparison of molecular rapid test instrument*

\begin{tabular}{|l|l|l|l|l|l|l|l|}
\hline Instrument & Samples & $\begin{array}{l}\text { FDA } \\
\text { EUA }\end{array}$ & Time & Method & Target & Sensitivity & Spesificity \\
\hline $\begin{array}{l}\text { Xpert } \\
\text { SARS-CoV- } \\
2\end{array}$ & $\begin{array}{l}\text { Nasopharyngeal } \\
\text { Swab, nasal } \\
\text { aspirate }\end{array}$ & Yes & $\begin{array}{l}45 \\
\text { minutes } \\
-1 \text { hour }\end{array}$ & RT-PCR & $\begin{array}{l}\text { N2 } \\
\text { E }\end{array}$ & $100 \%$ & $100 \%$ \\
\hline $\begin{array}{l}\text { VitaPCR } \\
\text { COVID-19 } \\
\text { assay }\end{array}$ & $\begin{array}{l}\text { Nasopharyngeal } \\
\text { and } \\
\text { Oropharyngeal } \\
\text { Swab }\end{array}$ & Pending & $\begin{array}{l}20 \\
\text { minutes }\end{array}$ & RT-PCR & $\begin{array}{l}\text { Viral } \\
\text { RNA }\end{array}$ & $100 \%$ & $100 \%$ \\
\hline $\begin{array}{l}\text { RapidPrep } \\
\text { COVID-19 }\end{array}$ & Swab or sputum & $* *$ & $\begin{array}{l}30 \\
\text { minutes }\end{array}$ & LAMP & $* *$ & $* *$ & $* *$ \\
\hline $\begin{array}{l}\text { ePlex } \\
\text { SARS-CoV- } \\
2\end{array}$ & $\begin{array}{l}\text { Nasopharyngeal } \\
\text { swab }\end{array}$ & Yes & 2 hour & RT-PCR & $\begin{array}{l}\text { Viral } \\
\text { RNA }\end{array}$ & $94,4 \%$ & $100 \%$ \\
\hline $\begin{array}{l}\text { Accula } \\
\text { SARS-CoV- } \\
2\end{array}$ & $\begin{array}{l}\text { Nasopharyngeal } \\
\text { and } \\
\text { Oropharyngeal } \\
\text { swab }\end{array}$ & Yes & $\begin{array}{l}30 \\
\text { minutes }\end{array}$ & $\begin{array}{l}\text { RT } \\
\text { PCR+Lateral } \\
\text { flow }\end{array}$ & N & $100 \%$ & $100 \%$ \\
\hline $\begin{array}{l}\text { ID Now } \\
\text { COVID-19 }\end{array}$ & $\begin{array}{l}\text { Nasopharyngeal } \\
\text { and } \\
\text { Oropharyngeal } \\
\text { swab }\end{array}$ & Yes & $\begin{array}{l}13 \\
\text { minutes }\end{array}$ & $\begin{array}{l}\text { Isothermal } \\
\text { nucleic acid } \\
\text { amplification }\end{array}$ & RdRp & $100 \%$ & $100 \%$ \\
\hline $\begin{array}{l}\text { POCKIT } \\
\text { SARS-CoV- } \\
2\end{array}$ & $\begin{array}{l}\text { Oropharyngeal } \\
\text { swab }\end{array}$ & No & $\begin{array}{l}85 \\
\text { minutes }\end{array}$ & $\begin{array}{l}\text { Insulated } \\
\text { isothermal } \\
\text { polymerase } \\
\text { chain reaction }\end{array}$ & Orf1ab & $* *$ & $* *$ \\
\hline
\end{tabular}

*Based on data at ${ }^{[21]}$ with modification

**No data

\section{Serology Examination}

Clinical symptoms of patients with COVID-19 are similar to general viral infections. The gold standard examination for the diagnosis of COVID-19 is rRT-PCR, but this examination has several drawbacks: a long time needed, a high level of complexity, special facility, the high priceof the equipment, and expert's laboratory staff required. Another drawback is the presence of false negative results on rRT-PCR. This makes rRT-PCR less suitable for rapid diagnosis and screening of patients. ${ }^{[3]}$

\section{Antibody Examination}

Examination of specific antibodies to SARS-CoV-2 using a patient's blood sample is the right choice for a quick, easy, and sensitive examination COVID-19 diagnosis. The selection of blood samples used is also important because studies in
Germany showed that the sensitivity of examinations using capillary blood samples was only $36.4 \% \cdot{ }^{[25]}$ After SARS infection, $\lg M$ is detectable in the blood after 7 days, then reaches a peak until 28 days and falls but can still be detected until the 42 day after onset. IgG antibodies can be detected after 10 days, then reach a peak of up to 49 days and last for a long time. Based on this data, it is recommended to monitor $\lg M$ and $\lg G$ antibodies for up to 18 and 21 days, respectively. Interpretation of $\lg G$ examination must be done carefully because the detection of $\lg G$ does not mean past infection since $\lg G$ can be detected early in the infection and last for a long time. Antibody titers are said to be related to the severity and clearance of viruses. Higher antibody titer is related with high severity, while lower antibody titer is related with high virus clearance. ${ }^{[17]}$ This examination is not 
affected by variations in the amount of virus at the time of examination, which is very influential on rRT-PCR. The biggest challenge of this examination is the presence of cross reactions with other coronaviruses. A study in Hong Kong conducted serological examinations in 15 COVID-19 patients, and the results obtained were high levels of cross-reaction between SARS-CoV-2 and SARS-CoV. ${ }^{[26]}$

A retrospective study in China showed that positivity rate of antibody examination at the early onset was low probably because antibodies were not yet developed. IgG antibodies had a higher positivity rather than $\lg M$ with percentages of $88.9 \%$ and $48.1 \%$, respectively. At the seroconversion phase in which the virus has not been detected, $\lg M$ also begins undetected, while $\lg G$ remains detected. ${ }^{[27]}$

A study in Shenzhen, China compared the examination of RNA, total antibodies, $\lg M$, and $\lg G$. This study showed that in the first 7 days after onset, RNA examination had the best sensitivity of $66.7 \%$. Starting on day 8 , total antibody sensitivity was better than RNA, even at 13 days after the onset, total antibody sensitivity reached $90 \%$. The sensitivity of $\lg G$ and $\lg M$ also exceeded RNA examination on days 8-14, but remained lower than total antibodies. This study showed that antibody testing also had good sensitivity in diagnosing COVID-19, especially total antibodies. Antibody tests might increase the sensitivity of RNA testing when combined. ${ }^{[28]}$

Examination of antibodies is currently being developed using recombinant $\mathrm{S}$ and $\mathrm{N}$ antigens from viruses. Using recombinant antigen means there is no need for biosafety level 3 for its work. Protein $\mathrm{N}$ is easier to clone, but the level of crossreaction is higher than protein S. Polyclonal antibodies obtained from SARS-CoV are able to neutralize SARS-CoV-2 because protein $S$ from these two viruses has $75 \%$ similarity of amino acids. ${ }^{[29]}$ Several studies conducted tests and validations on several antigens (RBD, N, S1) using the Enzyme-linked Immunosorbent Assay (ELISA) method. The results of the study indicate that protein $\mathrm{S} 1$ is more specific than protein $\mathrm{S}$ in detecting SARS-CoV-2 antibodies, whereas protein $\mathrm{N}$ is more sensitive than protein $\mathrm{S} .{ }^{[30]}$

There are several methods that can be used in SARS-CoV-2 serological examinations other than ELISA-based method. ${ }^{[31]}$ Immunofluorescence Assay (IFA) is a method for detecting antibodies by detecting fluorescent signals. The detected signal is produced by the interaction between the antibodies present in the sample and the virus antigen/protein that has been attached to the slide and observed using a fluorescent microscope. Abbott SARS-CoV-2 lgG is an instrument that uses the chemiluminescent microparticle immunoassay (CMIA) method to detect $\lg G$ qualitatively. The sample used is serum or plasma and is carried out using Architect. ${ }^{[32]}$

Lateral Flow Assay (LFA) is a method widely used to detect antibodies to COVID-19. This examination is in the form of a membrane coated with 2 kinds of lines; the first is an antibody with a gold conjugate and the second is an antibody capture. The patient sample is dripped in the membrane and the protein will be absorbed in the membrane. After this protein crosses the first line, the antigen will bind to antibodies with the gold conjugate and move to the second line. After arriving at the second line, this antigen-antibody complex will stop because it is captured by capture antibodies that it can emit a visible color. ${ }^{[8]}$

Recently, many companies are competing in making serological examinations using various methods. This makes it easier to do a quick and evenly examinations, but some instruments issued by many of these companies have not passed the validation test and approval by the authorities. In Indonesia, there are currently 22 kinds of serology tests that have been registered. This certainly needs to be aware of which instruments have been validated and approved. This is very important considering the results issued by the instruments used will have a major impact on efforts to prevent transmission of the COVID-19 outbreak. We present the data of instruments entered in our country in the Table 2.

Table 2: Serology examinations in Indonesia*

\begin{tabular}{|l|l|l|l|l|l|}
\hline No. & Name & Approval & Sensitivity & Specificity & Others \\
\hline & Wondfo SARS-COV-2 & FDA & Philippines, \\
1. & $\begin{array}{l}\text { Antibody Test (Lateral } \\
\text { HAS } \\
\text { Slow Method) }\end{array}$ & $\begin{array}{l}62.9 \% \\
\text { Capillary } \\
\text { Canada }\end{array}$ & $\begin{array}{l}\text { Serum } \\
95.4 \%\end{array}$ & $\begin{array}{l}95.2 \% \\
\text { Capillary } \\
100 \%\end{array}$ & {$[33]$} \\
\hline 2. & $\begin{array}{l}\text { VivaDiag } \\
\text { IgM/IgG Rapid Test }\end{array}$ & $\begin{array}{l}\text { HAS } \\
\text { Singapore, } \\
\text { Australia }\end{array}$ & $18.4 \%$ & $91.7 \%$ & {$[34]$} \\
\hline
\end{tabular}




\begin{tabular}{|c|c|c|c|c|c|}
\hline 3. & $\begin{array}{l}\text { HIGHTOP SARS-CoV-2 } \\
\text { IgM/lgG ANTIBODY } \\
\text { RAPID TEST }\end{array}$ & $\begin{array}{l}\text { FDA } \\
\text { Philippines, } \\
\text { Canada, } \\
\text { Australia }\end{array}$ & $* *$ & $* *$ & $* *$ \\
\hline 4. & $\begin{array}{ll}\text { VAZYME } & 2019-n C o V \\
\lg G / \lg M & \text { DETECTION } \\
\text { KIT } & \end{array}$ & $\begin{array}{l}\text { FDA } \\
\text { Philippines }\end{array}$ & $* *$ & $* *$ & $* *$ \\
\hline 5. & $\begin{array}{l}\text { Standar Q COVID-19 } \\
\lg M / \lg G \text { Duo }\end{array}$ & $\begin{array}{l}\text { FDA } \\
\text { Philippines }\end{array}$ & $\begin{array}{l}\lg G 100 \% \\
\lg M 100 \%\end{array}$ & $\begin{array}{l}\lg G 100 \% \\
\lg M 100 \%\end{array}$ & Insert Kit \\
\hline 6. & $\begin{array}{ll}\text { EAGLECARE } & \text { Novel } \\
\text { Coronavirus } & \text { (2019- } \\
\text { nCoV) IgG/lgM Test Kit } \\
\text { (Colloidal Gold) }\end{array}$ & Korea & $* *$ & $* *$ & $* *$ \\
\hline 7. & $\begin{array}{l}\text { Artron one step covid- } \\
19 \lg G \lg M \text { antibodi }\end{array}$ & $* *$ & $83 \%$ & $100 \%$ & [35] \\
\hline 8. & $\begin{array}{l}\text { qSARS-CoV-2 lgG/lgM } \\
\text { Rapid Test }\end{array}$ & $\begin{array}{l}\text { FDA US, } \\
\text { FDA } \\
\text { Philippines, } \\
\text { Australia }\end{array}$ & $93.75 \%$ & $96.40 \%$ & Insert Kit \\
\hline 9. & Qingdao & $\begin{array}{l}\text { FDA/EUA \& } \\
\text { FDA } \\
\text { Philippines }\end{array}$ & $* *$ & ** & ** \\
\hline 10. & Biotech & $\begin{array}{l}\text { FDA } \\
\text { Philippines }\end{array}$ & $* *$ & $* *$ & $* *$ \\
\hline 11. & Healgen & $\begin{array}{l}\text { FDA } \\
\text { Philippines }\end{array}$ & $* *$ & $* *$ & $* *$ \\
\hline 12. & 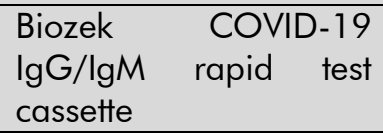 & FDA/EUA & $* *$ & $* *$ & $* *$ \\
\hline 13. & $\begin{array}{l}\text { GenBody COVID-19 } \\
\lg M / \lg G\end{array}$ & $\begin{array}{l}\text { Ministry of } \\
\text { Health } \\
\text { Jerusalem, } \\
\text { Israel }\end{array}$ & $\begin{array}{l}\lg G 100 \% \\
\lg M 80 \%\end{array}$ & $\begin{array}{l}\lg G 100 \% \\
\lg M 100 \%\end{array}$ & Insert Kit \\
\hline 14. & $\begin{array}{lr}\text { Clungene } & \text { COVID-19 } \\
\text { lgG/lgM rapid test } \\
\text { cassette (WB/S/P) }\end{array}$ & Korea & $* *$ & $* *$ & $* *$ \\
\hline 15. & $\begin{array}{l}\text { SGTi-flex COVID-19 } \\
\text { lgM/lgG Sugentech }\end{array}$ & Australia & $* *$ & $* *$ & $* *$ \\
\hline 16. & Prestige & $* *$ & $* *$ & $* *$ & $* *$ \\
\hline 17. & $\begin{array}{l}\text { Core Tests COVID-19 } \\
\lg M / \lg G \text { Ab Test }\end{array}$ & ** & $* *$ & ** & $* *$ \\
\hline 18. & $\begin{array}{l}\text { COVID-19 lgG/lgM } \\
\text { rapid test kit (Coloidal } \\
\text { Gold) Yilifang Biotech }\end{array}$ & $* *$ & $* *$ & $* *$ & $* *$ \\
\hline 19. & $\begin{array}{l}\text { Hangzhou Zheda } \\
\text { Dixun Biological }\end{array}$ & $* *$ & $* *$ & $* *$ & $* *$ \\
\hline 20. & Neomed & $* *$ & $* *$ & $* *$ & $* *$ \\
\hline 21. & Fenghua & $* *$ & $* *$ & $* *$ & $* *$ \\
\hline 22. & $\begin{array}{l}\text { COVID-19 } \\
\text { Coronavoris } \lg G / \lg M \\
\text { rapid test kit (R \& D) }\end{array}$ & $* *$ & $* *$ & $* *$ & $* *$ \\
\hline
\end{tabular}

* Data were collected on April 20, 2020

** No data

\section{Antigen Examination}

Other type of rapid tests available is detecting the presence of a protein (antigen) that is expressed by the COVID-19 virus from an airway sample. These antigens will bind to specific antibodies and emit readable signals. This antigen is only 
detected if the virus is actively replicating, so this examination is best used during an acute infection. ${ }^{[36]}$

Theoretically, viral antigens are specific markers and can be detected before antibodies are developed, so they can be used for screening. Researcher in China conducted a study using the fluorescence immunochromatographic method to detect $N$ proteins from SARS-CoV-2 using samples from nasopharyngeal swabs. In this study, $68 \%$ sensitivity and $100 \%$ specificity were obtained. ${ }^{[37]}$

\section{Diagnosis Protocol}

Many countries show great effort to diagnose SARS-CoV-2. South Korea successfully prevents the spread of COVID-19 by conducting largescale PCR tests. South Korea conducted more than 300,000 tests in 9 weeks after the first case was found there. Singapore uses mass testing, aggressive contact screening, and isolation. The country is screening all pneumonia patients and influenza-like symptoms in hospitals and primary health facilities. Taiwan and Hong Kong also use the same method by conducting mass tests to prevent transmission. ${ }^{\text {[38,39] }}$

The role of diagnostic testing is very important to deal with the large scale transmission diseases, such as COVID-19. The type of examination, the tools needed, and the time of the examination are very important to be considered to get optimal results. The choice of examination used must pay attention to several aspects, including the target being examined (viruses, antibodies), the time needed to issue results, the ability of the tool to examine several samples at once, and the ability of a device to be operated in various places with limited resources. FDA categorizes diagnostic examinations based on their complexity. The easiest examination can be done in point of care, while examinations with medium and high complexity must be done in the laboratory. This is also determined from what specimens can be checked on the device. The sensitivity and specificity of an examination must also play an important role in determining the selection of which tests are used for screening or those used for confirmatory. ${ }^{[13]}$

Indonesia has succeeded in producing its own RTPCR kit and rapid test. This RT-PCR kit is named NUSANTARA TRFIC-19. The target gene used by the Indonesian kit is the RdRp and $N$ genes. This kit is ready to be produced and is planned to produce 50,000 kits. The existence of this homemade kit is very helpful in screening and diagnosing COVID-19 in Indonesia. Validation tests are also carried out using Asian virus strains imported from overseas and local virus strains obtained from the Indonesian Health Research and Development Agency. ${ }^{[40]}$ COVID-19 screening in Indonesia uses Rapid Test (RT) antibodies and/or antigens for suspected COVID19 person. Antibodies examination is also used to detect cases in areas that do not have facilities for RT-PCR examination. The results of RT antibody tests are confirmed using RT-PCR. The protocol of COVID-19 examination in Indonesia can be seen in Figure 1. ${ }^{[41]}$ 


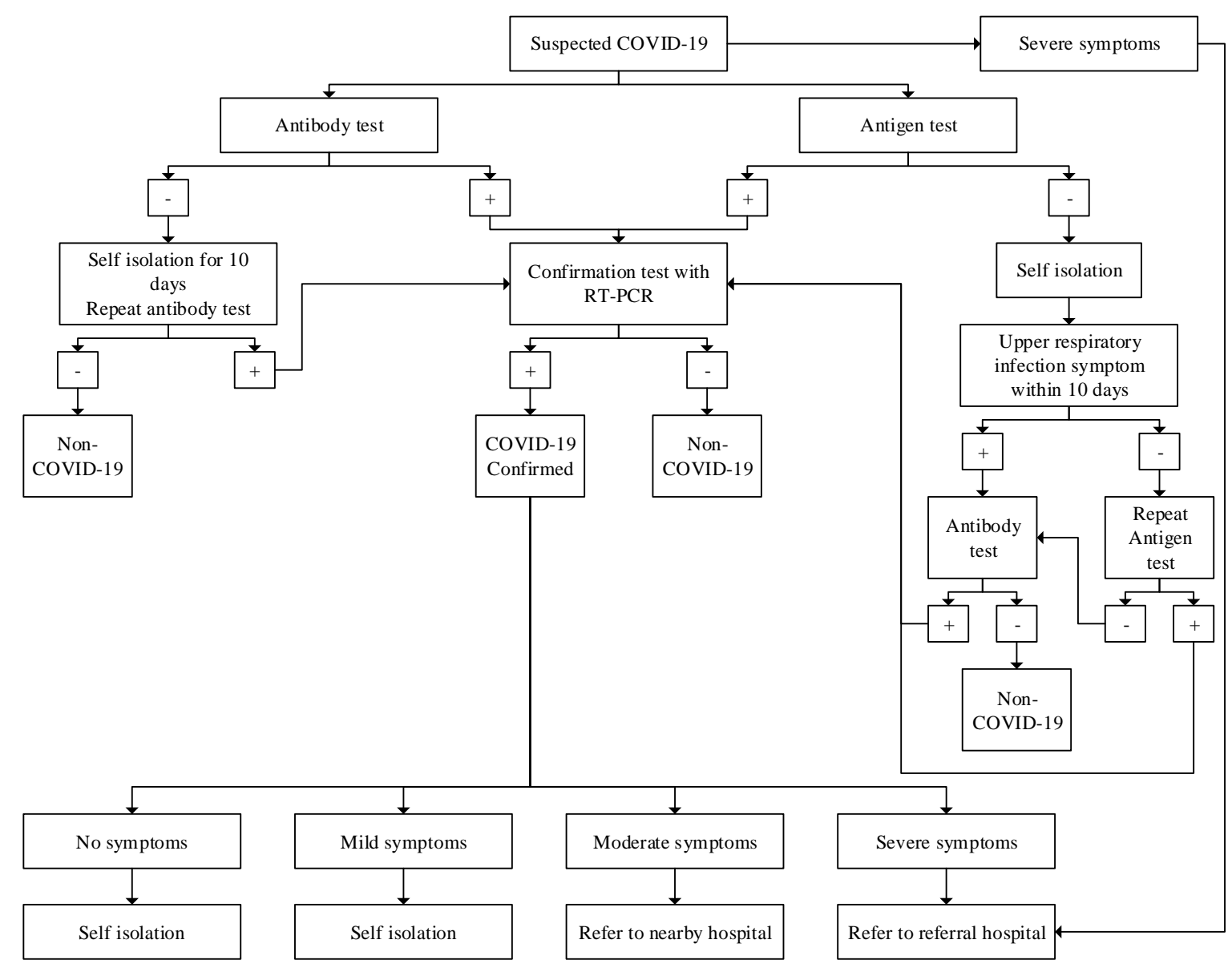

Fig.1:COVID-19 examination protocol in Indonesia ${ }^{[41]}$ with modification.

The mass examination is ideally performed by RTPCR because it directly confirms if there are positive results. Mass examination with antigen and antibodies rapid tests still need confirmation of RT-PCR. It takes longer time rather than using RT-PCR directly. However, in countries with very large populations and limited availability of PCR tools, rapid tests are ideal because they can cover large amounts of people in a short time. Therefore, validation of the tools used both rapid and RT-PCR is very important for the successful prevention of the spread of COVID-19.

\section{CONCLUSION}

COVID-19 is a disease that spreads very quickly, thus it is important to have quick and accurate diagnostic tools. Various modalities that have been developed are very helpful in overcoming this disease. The RT-PCR method is a gold standard method in diagnosing COVID-19. Several consideration is needed when using RT$P C R$, starting from the type of PCR machine used and the target gene used in the device. Serological examination must also consider the targets of detection, either antigen, total antibody, $\lg M$, or $\lg G$. The time of collection and type of specimen examined also need to be considered in all examinations. Validation of the modalities we used is important to achieve accurate result.

\section{ACKNOWLEDGMENTS}

This manuscript was funded by grants from the Hibah Riset Mandat Khusus Covid-19 2020 Grant from Universitas Airlangga.

\section{REFERENCES}

I. Zhu N, Zhang D, Wang W, Li X, Yang B, Song J, et al. A novel coronavirus from patients with pneumonia in China, 2019. N Engl J Med 2020;382(8):727-33.

2. Wang L, Wang Y, Ye D, Liu Q. A review of the 2019 Novel Coronavirus (COVID-19) based on current evidence. Int J Antimicrob Agents [Internet] 2020;105948. Available from: https://doi.org/10.1016/j.ijantimicag.2020.105948

3. Li Z, Yi Y, Luo X, Xiong N, Liu Y, Li S, et al. Development and Clinical Application of $A$ Rapid IgM-lgG Combined Antibody Test for SARS-CoV-2 Infection Diagnosis. J Med Virol 2020;0-I.

4. Weiss SR, Leibowitz JL. Coronavirus pathogenesis [Internet]. Ist ed. Elsevier Inc.; 20II. Available from: 
http://dx.doi.org// 0.1016/B978-0-12-3858856.00009-2

5. Lippi G, Plebani M. The critical role of laboratory medicine during coronavirus disease 2019 (COVID-19) and other viral outbreaks. Clin Chem Lab Med 2020;0(0):39-45.

6. Prestidge M, Amoore Z. Purpose and Options for Testing for SARS-Cov2 ( the COVID-19 virus ): Considerations for World Bank Task Teams Managing COVID-19 Fast Track Facility Operations [Internet]. Washington, D.C: 2020. Available from: http://documents.worldbank.org/curated/en/l 45 | 6 I 5865367 I 2080/Purpose-and-Options-forTesting-for-SARS-Cov2-the-COVID-19-VirusConsiderations-for-World-Bank-Task-TeamsManaging-COVID- 19-Fast-Track-FacilityOperations

7. Loeffelholz MJ, Tang YW. Laboratory diagnosis of emerging human coronavirus infections-the state of the art. Emerg Microbes Infect 2020;9(I):747-56.

8. Udugama B, Kadhiresan P, Kozlowski HN, Malekjahani A, Osborne M, Li VYC, et al. Diagnosing COVID-19: The Disease and Tools for Detection. ACS Nano 2020;0-28.

9. Fan BE, Chong VCL, Chan SSW, Lim GH, Lim $\mathrm{KGE}$, Tan GB, et al. Hematologic parameters in patients with COVID-19 infection. Am J Hematol 2020;2-9.

10. Lippi G, Plebani M. Laboratory abnormalities in patients with COVID-2019 infection. Clin Chem Lab Med 2020;20-3.

II. Guan WJ, Ni ZY, Hu Y, Liang WH, Ou CQ, He JX, et al. Clinical Characteristics of Coronavirus Disease 2019 in China. N Engl J Med 2020; I-I3.

12. Dong X, Cao Y, Lu X, Zhang J, Du H, Yan Y, et al. Eleven Faces of Coronavirus Disease 2019. Allergy 2020;(March): I-I I.

13. Corman VM, Landt O, Kaiser M, Molenkamp R, Meijer A, Chu DK, et al. Detection of 2019 novel coronavirus (2019-nCoV) by real-time RT-PCR. Eurosurveillance [Internet] 2020;25(3):I. Available from: https://www.eurosurveillance.org/content//0.28 07/I560-79I7.ES.2020.25.3.2000045

14. Shen M, Zhou Y, Ye J, Abdullah AL-maskri AA, Kang $\mathrm{Y}$, Zeng $\mathrm{S}$, et al. Recent advances and perspectives of nucleic acid detection for coronavirus. J Pharm Anal [Internet] 2020;(January). Available from: https://linkinghub.elsevier.com/retrieve/pii/S209 5177920302082

15. Zhang W, Du RH, Li B, Zheng XS, Yang X Lou, $\mathrm{Hu} B$, et al. Molecular and serological investigation of 2019-nCoV infected patients: implication of multiple shedding routes. Emerg Microbes Infect 2020;9(I):386-9.

16. National Center for Immunization and Respiratory Diseases (NCIRD) D of VD.
Interim Guidelines for Collecting, Handling, and Testing Clinical Specimens from Persons for Coronavirus Disease 2019 (COVID-19) [Internet]. Cdc2020;2019-21. Available from: https://www.cdc.gov/coronavirus/2019ncov/lab/guidelines-clinical-specimens.html

17. Tan W, Lu Y, Zhang J, Wang J, Dan Y, Tan Z, et al. Viral Kinetics and Antibody Responses in Patients with COVID-19. medRxiv [Internet] 2020;2020.03.24.20042382. Available from: http://medrxiv.org/content/early/2020/03/26/20 20.03.24.20042382.abstract

18. Johnson M. PCR Machines [Internet]. Labome2013;3:I-I4. Available from: http://www.labome.com/method/PCRMachines.html

19. John Hopkins Center for Health Security. Comparison of National RT-PCR Primers, Probes, and Protocols for SARS-CoV-2 Diagnostics [Internet]. centerforhealthsecurity.org2020;5. Available from:

https://www.centerforhealthsecurity.org/resour ces/COVID- I 9/COVID- I9-fact-sheets/2004I0RT-PCR.pdf

20. Hasell J, Ortiz-Ospina E, Mathieu E, Ritchie H, Beltekian D, Macdonald B, et al. Statistics and Research Coronavirus (COVID-19) Testing [Internet]. Our World Data2020 [cited 2020 May 22];II8. Available from: https://ourworldindata.org/coronavirus-testing

21. Hogan CA, Caya C, Papenburg J. Rapid and simple molecular tests for the detection of respiratory syncytial virus: a review. Expert Rev Mol Diagn [Internet] 2018;18(7):617-29. Available from: https://doi.org//0.1080/|4737| 59.2018.|487293

22. Vashist SK. In Vitro Diagnostic Assays for COVID-19: Recent Advances and Emerging Trends. Diagnostics (Basel, Switzerland) [Internet] 2020;10(4). Available from: http://www.ncbi.nlm.nih.gov/pubmed/3226047I

23. Notomi $\mathrm{T}$, Okayama $\mathrm{H}$, Masubuchi $\mathrm{H}$, Yonekawa T, Watanabe K, Amino $\mathrm{N}$, et al. Loop-mediated isothermal amplification of DNA. Nucleic Acids Res [Internet] 2000;28(I2):e63. Available from: https://watermark.silverchair.com/2800e63.pdf?t oken=AQECAHi208BE49Ooan9kkhW_Ercy7D m3ZL_9Cf3qfKAc485ysgAAAmYwggjiBgkqhkiG 9w0BBwagggJTMIICTwIBADCCAkgGCSqGSIb3 DQEHATAeBglghkgBZQMEAS4wEQQMy3AQ PdcwVpshAVulAgEQgllCGSfU5ehJRqbly2A_4p dI2_oNbrQem7FM_kTE9ZYQL40XC4I

24. Bhadra S, Jiang $Y S$, Kumar MR, Johnson RF, Hensley LE, Ellington AD. Real-time sequencevalidated loop-mediated isothermal amplification assays for detection of Middle East respiratory syndrome coronavirus (MERS-CoV). PLoS One 2015; I0(4): I-2I. 
25. Döhla M, Boesecke C, Schulte B, Diegmann C, Sib E, Richter E, et al. Rapid point-of-care testing for SARS-CoV-2 in a community screening setting shows low sensitivity. Public Health 2020; 182: I70-2.

26. Lv H, Wu NC, Tsang OT-Y, Yuan M, Perera RAPM, Leung WS, et al. Cross-reactive antibody response between SARS-CoV-2 and SARS-CoV infections. bioRxiv [Internet] 2020;2020.03.15.993097. Available from: https://www.biorxiv.org/content/ / 0.1 I 0 I/2020.0 3.| $5.993097 \mathrm{vl}$

27. Jin Y, Wang M, Zuo Z, Fan C, Ye F, Cai Z, et al. Diagnostic value and dynamic variance of serum antibody in coronavirus disease 2019. Int J Infect Dis [Internet] 2020;94:49-52. Available from: https://doi.org/10.1016/j.ijid.2020.03.065

28. Zhao J, Yuan Q, Wang H, Liu W, Liao X, Su Y, et al. Antibody responses to SARS-CoV-2 in patients of novel coronavirus disease 2019. Clin Infect Dis 2020; $1-22$.

29. Infantino M, Damlani A, Gobbi FL, Grossi V, Lari B, Donatella M, et al. Serological Assays for SARS-CoV-2 Infectious Disease: Benefits, Limitations and Perpectives. Isr Med Assoc J 2020;22(4).

30. OKBA NMA, Muller MA, Li W, Wang C, GeurtsvanKessel $\mathrm{CH}$, Corman VM, et al. SARSCoV-2 specific antibody responses in COVID19 patients. medRxiv [Internet] 2020;2020.03.18.20038059. Available from: https://www.medrxiv.org/content/10.1 I01/2020. 03.|8.20038059v|

31. John Hopkins Center for Health Security. Serology testing for COVID-19 [Internet]. Johns Hopkins Bloom. Sch. Public Heal.2020 [cited 2020 Apr 29];2-3. Available from: https://www.centerforhealthsecurity.org/resour ces/COVID-19/COVID-19-fact-sheets/200228Serology-testing-COVID.pdf

32. Wu HS, Chiu SC, Tseng TC, Lin SF, Lin JH, Hsu YF, et al. Serologic and Molecular Biologic Methods for SARS-associated Coronavirus Infection, Taiwan. Emerg Infect Dis 2004; I0(2):304-10.

33. Tim Tanggap COVID-19 Jawa Barat. Laporan akhir uji validasi 12 April 2020_Final [Internet]. PDS PatKLIn2020 [cited 2020 May I0];14. Available from: https://www.pdspatklin.or.id/

34. Cassaniti I, Novazzi F, Giardina F, Salinaro F, Sachs M, Perlini S, et al. Performance of VivaDiag COVID-19 IgM/lgG Rapid Test is inadequate for diagnosis of COVID-19 in acute patients referring to emergency room department. J Med Virol 2020; I-4.

35. Lassaunière $R$, Frische $A$, Harboe $Z B$, Nielsen $A C Y$, Fomsgaard A, Karen A, et al. Evaluation of nine commercial SARS-CoV-2 immunoassays. medRxiv 2020; I-I5.

36. Li X, Geng M, Peng Y, Meng L, Lu S. Molecular immune pathogenesis and diagnosis of COVID19. J Pharm Anal [Internet] 2020;Available from: https://doi.org/ 10.1016/j.jpha.2020.03.00 I

37. Diao B, Wen K, Chen J, Liu Y, Yuan Z, Han C, et al. Diagnosis of Acute Respiratory Syndrome Coronavirus 2 Infection by Detection of Nucleocapsid Protein. medRxiv 2020;2020.03.07.20032524.

38. Sheridan C. Fast, portable tests come online to curb coronavirus pandemic. Nat Biotechnol [Internet] 2020;38(5):5I5-8. Available from: http://www.nature.com/articles/d4I587-02000010-2

39. Korean Society of Infectious Disease. Report on the epidemiological features of coronavirus disease 2019 (covid-19) outbreak in the republic of korea from january 19 to march 2, 2020. J Korean Med Sci 2020;35(I0): I-II.

40. Rahman AF. Prototipe Test Kit qPCR COVID19 Buatan Indonesia Rampung [Internet]. detik.com2020;1-7. Available from: https://inet.detik.com/cyberlife/d4965773/prototipe-test-kit-qpcr-covid-19. buatan-indonesia-rampung

41. Direktorat Jenderal Pencegahan dan Pengendalian Penyakit. Pedoman COVID REV-4. 4th ed. Jakarta: Kementrian Kesehatan Republik Indonesia; 2020. 